\title{
The Historical Development of Medial /ee/ and /oo/ in Hausa
}

\author{
PAUL NEWMAN
}

\section{INTRODUCTION}

In recent years a number of discoveries have been made conceming the historical development of Hausa consonants (see summary in Newman 1977:13-14). These findings, taken in the context of broader comparative Chadic studies, have permitted us to relate Hausa to its sister languages in a systematic way, identify true cognates, and thus come to an understanding of the likely consonant system of Proto-Hausa and of the nature and sequence of various changes that have taken place from then to the present.

By contrast, Hausa vowels (like vowels in comparative Chadic work in general) have been terribly neglected. The pioneer work on West Chadic vowels by Schuh (1978), however, finally provides the much-needed impetus for the historical study of Hausa vowels as well as the essential foundation on which such study can be based. While the major concern of Schuh's study is the Bole group (his "Bole-Tangale" group), he also discusses Hausa in some detail and outlines what in his opinion the ProtoHausa vowel system is most likely to have been. The purpose of the present paper is to carry forward Schuh's work by providing a more accurate picture of the Proto-Hausa rowel system and a more detailed account of subsequent historical developments. This historical analysis also leads to a natural phonological explanation for morphologically conditioned cases of ablaut and vowel alternation in present-day Hausa. The central question treated in this paper concerns the origin and development of the vowels $e e$ and 00 in medial position, for which I propose to provide an

- This work was supported by an NSF grant BNS77-16841, awarded to the Center for Applied Linguistics. I am grateful to Russell Schuh for having provided me with the full text of an as yet unpublished conference paper (Schuh 1978), without which the present paper would have been impossible. 
integrated, internally consistent model. I should emphasize internally consistent, since the historical model being presented is based primarily on internal reconstruction and only secondarily on comparative evidence.

\section{PROTO-HAUSA VOWEL SYSTEM}

A major methodological/conceptual advance in Schuh's study is the realization that the "vowel system" of Proto-Bole (and presumably that of Proto-West Chadic and even Proto-Chadic) is really a composite of coexisting vowel systems within the same language depending on the position of the vowels within the word. In initial position, Proto-Bole (PB) is reconstructed with 2 vowels, $i$ and $*$, while in final position it is reconstructed with 5 vowels, $i,{ }^{*},{ }^{*}, *$, $u$. In neither position is length distinctive, the normal realization being short. ${ }^{1}$ In medial position, on the other hand, length has to be taken into account. Here, PB is reconstructed with 2 short

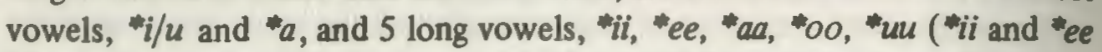
being reconstructed on systematic rather than comparative grounds).

Since Hausa and Bole are sister groups within the same subbranch of Chadic - Hausa being I.A.1 and Bole I.A.2 according to the Newman (1977) classification - one would expect the vowel systems of Proto-Hausa (PH) and PB to be similar, although not necessarily identical. In initial position, $\mathrm{PH}$ does seem to match $\mathrm{PB}$ exactly in having the same two vowels only, $i$ and $*$. In present-day Hausa this system is obscured because the language no longer has vowels initially, all words now obligatorily beginning with a consonant. It is easy to demonstrate, however, that at an earlier period Hausa did allow vowel-initial words and that the present-day phonotactic restriction was achieved by the phonemicization of [?] and [ $h]$ (see Newman 1976), e.g. Pidòo 'eye' < *ido, cf. Karekare idó; hancii 'nose' $<$ *antin, cf. Pa'a atin. ${ }^{2}$

Similarly, it seems reasonable to postulate 5 vowels in final position for $\mathrm{PH}, *, *, *, *, *$, and to match these with the corresponding PB final vowels. Although cognates between Hausa and Bole group languages are hard to find for some of the vowels (especially /e/), the internal and comparative evidence taken as a whole supports the view that all 5 vowels were fully phonemic in PH and that they had been inherited as such from a much earlier period. Synchronically, all 5 final vowels of Hausa exhibit a length distinction, and in nouns, at least, the long vowels clearly have the unmarked value. As suggested independently by Greenberg (1978) and Schuh (1978), these long vowels (and the resulting length contrast) can best be explained, not phonologically, but in terms of a historical morphological development from a lost article. ${ }^{3}$ In $\mathrm{PH}$, we can assume that the final vowels were short, as postulated for PB.

Regarding the medial vowels, Schuh notes that correspondences between 
Hausa and the Bole group are difficult to establish (this also being true for some vowels even within the Bole group). Nevertheless, he claims that the PH medial vowel system is likely to have been the same as that of PB, i.e. containing one high and one low short vowel plus 5 long vowels. In this case, Schuh is probably wrong. Whether the medial vowel system reconstructed for PB is correct or not - and I have my doubts - this could not have been what the PH system looked like. It is true that modern Hausa has come to have a medial vowel system strikingly similar to the postulated PB one, but I would nevertheless propose that the proto-language had a very different system. Specifically, in place of the system with 2 short and 5 long vowels, I would propose a simple system based on 3 vowels, $i, a$, all of which could occur either long or short.

\subsection{Medial short vowels}

In a rich and highly imaginative treatment of Hausa phonology, Parsons (1970) argues that, synchronically speaking, Hausa can be analyzed as having only 2 underlying medial (i.e. non-final) short vowels: a high vowel $I / U$ and a low vowel $a$. The claim is that medial $i$ and $u$ are non-contrastive variants of the same phoneme, the surface realization depending on the nature of the adjacent consonant(s). The difference in the first syllable of pairs such as budialbidaa 'bespatter'/'seek', turia/ciròa 'dye'/lift up', zumia/jimàa 'honey'/'delay', sùngaa/shingee 'throw'/'termite', gùdaa/gidaa 'unit'/'house' is thus said to lie in the consonants and not in the difference between $i$ and $u$ as traditionally described.

Schuh (1978) enthusiastically endores Parsons' analysis, not only as the synchronic tour de force that it is, but also as an accurate historical picture. But on closer look, it becomes clear that Parsons' analysis cannot be accepted so readily.

In the first place, the analysis presents a number of serious problems that cast doubt about its adequacy even at the purely synchronic level. For example, in treating palatals, Parsons' system requires that the identical syllable [ii] in jikii 'body' and in na-miji 'male' be analyzed phonemically in opposite ways: $|j|+|I| U \mid$ in the first case, $/ z|+| i \mid$ in the second. Worse still, in a trisyllabic word such as bincikaa 'inquire into', it is impossible to account for the $[c]$, since Parsons doesn't have underlying palatal consonants except in initial position, but neither can he have it conditioned by the following $[i]$, which is merely a surface variant of the neutral vowel $/ I / U /$. A different kind of problem is seen in the dialect variants sanii = shinia 'to know' or sabii = shibia 'teasing cotton' (parallel to barii = biràa 'to leave'), where Parsons (1970:287) is forced to appeal to a "suprasegmental Y-coloration change" to account for the shinia/shibaia forms since the obvious explanation, i.e. vowel metathesis followed by automatic palatalization of the $/ s /$ in the environment of a front vowel, runs counter 
to his theory.

In the second place, Parsons' analysis is historically at odds with the internal and comparative evidence, which supports the idea that medial /i/ and $/ u /$ were in contrast. ${ }^{4}$ However one might view Parsons' phonological approach for a synchronic analysis of Hausa, historically the contrast in pairs such as zumaia/jimaia clearly lay with the vowels while the difference in the consonants was conditioned and secondary. ${ }^{5}$ Examples of palatal consonants reflecting an alveolar in the environment of what must be considered a distinctively high front medial vowel include jikii 'body' < "ziki, cf. Bole ziwò; jîka 'become wet' < "zika, cf. Kanakuru yèke; ciri 'pull out' (pre-noun form) < *tìri, cf. Galambu tál- (cf. tunkìał 'sheep' < "tumki, where the / $t /$ preceding / $u /$ has not palatalized). I conclude, therefore, that PH did have a contrast between medial short /i/ and $|u|$ and that it thus had 3 , not 2 , short vowel phonemes in medial position, $*$, * $a$, $u$, all three of which could presumably occur in closed as well as open syllables.

\subsection{Medial long vowels}

In medial position Hausa has 5 long vowels, $i i, e e, a a, o o, u u .^{6}$ (The description and discussion here refer only to open syllables since Hausa does not allow long vowels in closed syllables.) Since all five of these vowels occur freely and in contrast in normal, native words, it would seem reasonable to reconstruct them as such for $\mathrm{PH}$ and to match them with the corresponding long vowels reconstructed for PB. There are, however, phonotactic co-occurrence patterns concerning the mid vowels $e e$ and $o o$ which previously have not been noted, but which are of critical historical importance.

If one takes a list of common Hausa nouns of the form CVCV, e.g. Parsons (n.d.), one finds that almost all the nouns with a mid vowel as the first vowel also have a mid vowel as the final vowel, e.g. beebee 'mute', geerò 'millet', toozoo 'hump', zoobèe 'ring'. There are exceptions, e.g. reemaa 'coney', goonaa 'farm', but these are few. Conversely, nouns with ii or $u u$ in the first syllable normally do not end in a mid vowel. Words such as riigaa 'gown', kiifii 'fish', bùuraa 'penis', tùuluu 'water-pot', and suurii 'ant-hill' are common while jiigòo 'pole of shadoof' and tuushee 'base', for example, are phonotactically unusual. Thus, rather than being completely independent, as generally assumed, the long mid vowels and the long high vowels can be seen to be in partial complementary distribution, depending on the nature of the (historically stable) final vowel. Synchronically the mid and high vowels are clearly contrastive; but in most cases this contrast can be explained by one natural historical process or another, leaving very few examples unaccounted for. I would suggest, therefore, that ee and oo did not exist as separate phonemes in PH, but 
rather were simply allophones of $i i$ and $u u$, respectively. In other words, PH had 3 (not 5) medial long vowels, corresponding to the 3 short vowels also occurring in that position.

\section{THE ORIGIN OF ee AND OO}

2.1. The medial mid vowels that are now found in Hausa have three sources, one phonologically regular, the other two sporadic, but important in bringing about phonemic contrast. The major source of the mid vowels was the assimilation of long $i i$ and $u u$ to a mid vowel in the following (final) syllable, i.e.

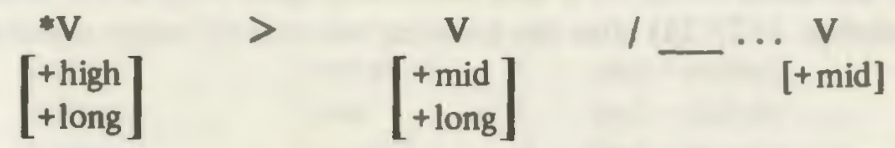

Presumed examples of words having undergone this change are:

"biibe $>$ beebee 'mute' "tuuzo $>$ toozoo 'hump'
"kiisò > keesòo 'mat' "zuubè > zoobèe 'ring'

The rule did not apply to short $i$ and $u$, which explains why short $e$ and 0 do not occur medially in Hausa even though these vowels do occur short in final position. In looking at cognates, one finds that the long mid vowels commonly correspond to short vowels elsewhere, e.g.

(3) Hausa

$\begin{array}{ll}\text { 'spit' } & \text { toofee } \\ \text { 'hare' } & \text { zoomoo } \\ \text { 'spew' } & \text { feesoo } \\ \text { 'hut' } & \text { beenee }\end{array}$

Other West Chadic

$\begin{array}{ll}\text { Bole } & \text { túfü } \\ \text { Kulere } & \text { sumór } \\ \text { Kirfi } & \text { fish- } \\ \text { Goemai } & \text { pin }\end{array}$

If the sound law as formulated in (1) is basically correct, then the medial " $i$ 's and " $u$ 's in the above examples would have already had to have been long when the lowering took place. What we do not know is whether pre$\mathrm{PH}$ underwent a lengthening rule $i$ and $u>i$ and $u u$ (under certain circumstances to be determined) or whether the long high vowels in these cases represent retentions from Proto-West Chadic which were lost in the other languages.

The vowel lowering was presumably an automatic phonological rule. Apparent exceptions are thus due to changes affecting either the medial vowel or the final vowel that occurred after this very early rule. For 
example, the addition of the feminine endings -(iy) laa and -(uw) aa (see Newman 1979), which resulted in long mid vowels occurring before $i / u$ instead of the expected $e / 0$, must have taken place after the lowering rule had already had its effect, e.g.

\begin{tabular}{|c|c|c|c|c|}
\hline tooliyaa & 'tuft' & $<$ & "toole-aa & "tuule \\
\hline beeguwaa & 'porcupine' & $<$ & *beego-aa & "biigo \\
\hline tootüwad & 'pulp' & $<$ & "tootò-aa & "tuutd \\
\hline duudriwaa & 'a song' & $<$ & "duudù-aa & *duudi \\
\hline
\end{tabular}

Examples of long high vowels followed by a mid vowel that have not changed are most often uu's that have developed from a VC sequence (Klingenheben 1927/28) after the lowering rule was no longer operational, e.g.

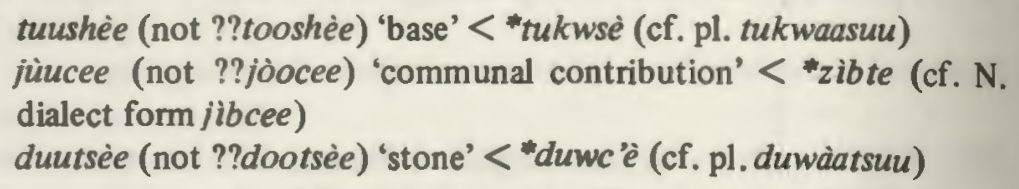

Other examples include new creations (e.g. kuurèe 'male hyena' < kuurca 'hyena'), sporadic lengthening (e.g. buushiyaa 'hedgehog' < bushiyaa < "buse), ${ }^{7}$ and loanwords (e.g. dattiijo 'gentleman', from Fula).

2.2. A second source of the mid vowels has been the sporadic change of long $a a$ to ee/oo following palatal(ized) and labialized consonants, respectively. While the more systematic changes in Hausa concern the effect of vowels on consonants (see sec. 1.1), the opposite does also take place, e.g.

$$
\begin{aligned}
& \text { ceeraa 'crowing of cock' < and = caaraaa. } \\
& \text { c'eereeriyaa 'brown bean' < "c'auraariyaa }
\end{aligned}
$$

Compare this Sokoto dialect form with the initial palatal $c^{\prime}$ with the Standard Hausa tsaararriyaa, where the $a a$ in the environment of the alveolar $t s(=[s])$ does not front.

$$
\text { ceediyaa 'fig tree' < "caadiyaa ( }<\text { "coade) }
$$

Note the plural form cèedàkuu, normally limited to nouns with a long $a a$ in the first syllable.

$$
\text { jeejii 'bush' } \left.<*^{*} j a j i i \text { ( }<\text { and }=\text { daajii }\right)
$$


It is standard to relate the two variants jeejii/daajii by a sporadic vowel change of aa to ee, followed by automatic palatalization of the initial $d$ to $j$. I would suggest that the order of change could just as easily have been the reverse, i.e. initial $d$ went to $j$ anticipating the $j$ in the second syllable, followed by the aa $>$ ee change in the environment of the two palatals.

\section{goonea 'farm' $<$ and = gwaanaa}

koodia 'kidney' $<$ and = kwaodia

2.3. The third source of ee/oo has been the sporadic monophthongization of $a i$ and, less often, $a u$, a recent process that is still in evidence, e.g.

$\begin{array}{ll}\text { seemaa } & \text { 'container' }<\text { and = saimaa } \\ \text { deeniaa } & \text { 'cease' }<\text { and = dainaia } \\ \text { loomàa } & \text { 'morsel' }<\text { and = loumáa } \\ \text { dookii } & \text { 'horse' }<\text { *daukii }(<\text { *dowki, cf. pl. dawaakii) }\end{array}$

2.4. With the establishment of ee and 00 as distinct phonemes, their incidence has continued to increase, especially due to the addition of loanwords, e.g.

$\begin{array}{lll}\text { teelà } & \text { 'tailor' } & \text { mootàa } \\ \text { feegi } & \text { 'peg' } & \text { jooji }\end{array}$

2.5. The most important unexplained 00 is the one that is found in the oCi plural formation, e.g. tsuulà 'blue monkey', pl. tsuuloolii; jiikcia 'grandchild', pl. jiikookii. This, however, is probably not so much a problem of phonology as it is of historical morphology, i.e. how to account for the development of this particular plural formation, which, as Parsons $(1975: 439)$ has claimed on other grounds, is almost certainly historically recent.

\section{SYNCRONIC VOWEL ALTERNATIONS INVOLVING THE MID VOWELS}

The effects of conditioned historical sound changes are often to be seen synchronically in grammatically conditioned ablaut. Or, to put it differently, synchronic morphological alternations often have as their explanation historically earlier phonological rules which no longer apply, either because the original conditioning environment has been obliterated or because the rules are simply no longer productive.

In Hausa, the discovery of the vowel lowering rule *ii/uu $>$ ee/oo allows us to account in a natural way for certain constructions involving 
synchronic vowel alternations which formerly were treated as completely unrelated. One is the seldom-discussed alternation between verbs and corresponding ablauted verbal nouns; the other is the well-known (but unexplained) alternation between pre-noun and pre-pronoun forms of grade 2 (= "changing") verbs. This is not to say that the historical sound change in itself solves all the problems in connection with these construction but it seems clear that the sound change lies at the heart of these presentday alternations and thus that it provides the key for understanding how these alternations came about.

\subsection{Ablauted secondary verbal nouns}

In addition to its normal verbal nouns, Hausa has functionally similar verbal nouns, which, since Abraham (1959), have come to be known as "secondary verbal nouns" (2vn's). Among the many morphologicd forms of $2 \mathrm{vn}$ 's, there is one characterized by final - ad, Hi-Lo tone, and an ablauted medial vowel. The following list shows that this formation type is less rare and less "irregular" than usually implied.

\begin{tabular}{|c|c|c|c|c|c|}
\hline & Verb & $2 v n$ & & Verb & $2 v n$ \\
\hline ‘flay' & feedàa & fiidàa & 'beat' & dòokaa & duukòo \\
\hline 'pare' & feerèe & fiirèa & 'rub' & gòogaa & gungia \\
\hline "throw at" & jèefoa & jüfohe & 'sharpen' & koodàn & kuudàa \\
\hline 'tan' & jeemia & jiimàa & 'pierce' & sòokaa & suukda \\
\hline 'smith' & keeria & kiiròa & 'scratch' & soosia & suusàa \\
\hline 'scrape' & rèedạ & riidàa & 'fry' & sooycia & suuycia \\
\hline 'shake' & reegàa & riigda & 'burn' & tooyàa & tuuyàa \\
\hline 'winnow' & sheekda & shiikàa & & & \\
\hline 'comb out' & tseefèe & tsiifäa & & & \\
\hline ‘dip out’ & deẹbèe & diibàa & & & \\
\hline
\end{tabular}

Surprisingly, this formation type has received little attention by Hausaists in spite of its somewhat unusual status within the language and the importance traditionally ascribed to ablaut in typological/comparative studies (e.g. Klingenheben 1930/31; Lukas 1937/38). It has just been taken for granted that morphologically-conditioned ablaut occurs in the formation of these particular $2 \mathrm{vn}$ 's and that the change is from the mid vowels ee and $o 0$ to the high vowels $i i$ and $u u$, respectively. Viewed historically, however, it seems clear that the basic mechanism was phonological, not morphological, and that the direction of change was the reverse, i.e. that it is the $2 v n$ form with its long high medial and neutral final vowel which 
has preserved the original medial vowel whereas the present-day verb forms are the result of the application of the general vowel lowering rule. The $2 \mathrm{vn}$ 's firìa and guugia, for example, would thus originally have been derived, not by a process of ablaut, but by direct addition of an - aa suffix and Hi-Lo tone to the lexical roots *fir- and "guug-, which underlay all related verbal and nominal forms. The alternation in the root vowel that now exists between verbs and $2 \mathrm{vn}$ 's, and which synchronically has to be described by an ad hoc ee/oo $\rightarrow i i / u u$ rule, is due to the fact that the verb forms have undergone the historically regular *ii/"uu > ee/oo change.

3.1.1. The above analysis of course requires that the verb have had a final mid vowel in at least some form(s) in order to condition the vowel lowering. Since internal evidence clearly favors a front vowel, ${ }^{9}$ the presumed final mid vowel must have been $-e$. The analysis also requires that one or a combination of these forms with $-e$ have been important enough to serve as the basis for a new, generalized verb base on which all verb forms would then be built. The following examples illustrate the hypothetical development:

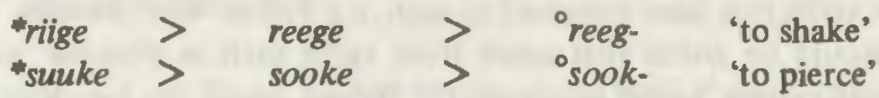

The hypothesis that Hausa verbs were remodelled on a form ending in $-e$ seems likely. Indentifying this form is a more difficult question. One possibility is that is was the pre-pronoun verb form with final -ee, e.g. taa dookee ni 'she beat me'. Although the verbs in (12) are listed in three different "grade" forms, ${ }^{10} \mathrm{gr} .1, \mathrm{gr} .2$, and $\mathrm{gr} .4$, they all can be assumed to have originally been gr. 2 verbs, i.e. the historical reflexes of the Chadic "schwa-class" (Newman 1973, 1975; Schuh 1977). They all would thus have had a pre-pronoun form with final -ee (see sec. 3.2), and this form, in contrast to the pre-noun form with final $-i$ (the underlying form), would necessarily have had a lowered medial vowel, e.g.

(14) Pre-pronoun form

Pre-noun (basic) form

$\begin{array}{llll}\text { fèeree } & \text { (not ??firee) } & \text { vs. *firi } & \\ \text { rèedee } & \text { (not??riidee) } & \text { vs. *riidí } & \\ \text { dòokee } & \text { (not??diukee) } & \text { vs. *diuki } & \text { (cf. PB *duku) } \\ \text { sòoyee } & \text { (not??sùuyee) } & \text { vs. *sùuyi } & \text { (cf. PB "suru) }\end{array}$

Similarly, grade 4 (totality) verbs and statives have a final -e(e) and thus also would have required that the stern vowel be mid, e.g. 


$$
\begin{aligned}
& \text { gr. } 4 \text { reegèe (not ??riigèe) } \\
& \text { gr. } 4 \text { googèe (not ??guugèe) } \\
& \text { stative tsèefe (not ??tsiife) } \\
& \text { stative tòoye (not ??tùuye) }
\end{aligned}
$$

Even if one cannot determine at this time precisely what the form with $-e$ was that conditioned the lowering of the stem vowels, one can be sure that it was an essential form in the verbal system as a whole and not limited to just those verbs that in present-day Hausa happen to have corresponding ablauted $2 \mathrm{vn}$ 's. Almost all verbs with medial $e e$ and oo can thus be presumed originally to have had medial $i i$ and $u u$ even though they may not synchronically exhibit alternations involving these vowels, e.g.

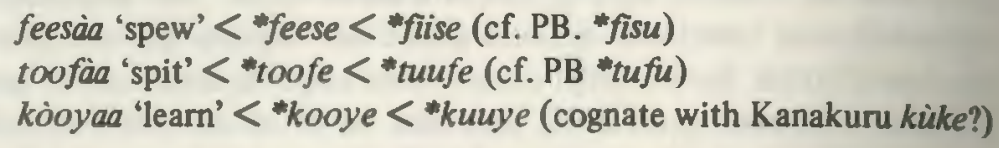

As in the case of the surface exceptions to the vowel lowering rule in nouns, some explanation will have to be found for the long high vowels found in verbs that have remained as such, e.g. ciizaa 'bite', buudèe 'open'. But it should be noted that apart from verbs such as shuukda 'sow' (< "sipka) and cùuraa 'knead into balls' (< "tibra), where the long high vowel has come from a lost syllable-final consonant, medial long high vowels in Hausa verbs are much less common than the corresponding mid vowels.

\subsection{Vowel alternation in grade 2 verbs}

The vowel alternation in Hausa that has best captured the attention of linguists is that found in the "changing verbs" (Abraham 1959), i.e. the grade 2 verbs of Parsons (1960). The alternation here is between final $-a a$, $-e e$, and $-i$ depending on whether the verb has no direct object, a pronoun direct object, or a noun direct object, e.g.

$\begin{array}{ll}\text { tae sàyae } & \text { 'she bought (it)' } \\ \text { tae sàyee sù } & \text { 'she bought them' } \\ \text { tae sàyi zanèe } & \text { 'she bought a cloth' }\end{array}$

In Newman (1973) I suggested that the alternation could be seen as less arbitrary than usually assumed if (a) the form with $-i$ were taken 13 basic, ${ }^{11}$ (b) the final -ee were viewed as phonologically derived from $-i$ vi an intermediate stage in which the underlying $-i$ (like all verb- final vowels) was lengthened before a pronoun object, and (c) the final - $a a$ were seen coming from a different morphological form and not derived in any dire sense from the underlying verb form with $-i_{0}{ }^{12}$ 
The major problem with proposal (b), the only one of the three that I shall discuss here, was that there didn't seem to be any phonological reason in present-day Hausa why lengthened $-i$ should change to ee. Now that we have a historical vowel lowering rule, we can assume that it was in some way responsible for the $-i /$-ee alternation. The explanation for the conditioning environment, however, turns out to be extremely complicated, depending on a complex interplay of phonological and morphological factors. Without going into a full discussion of the details, I would like to sketch out the general lines of the probable development.

3.2.1. West Chadic languages commonly have two different object pronoun paradigms: one is a "free" set, typically used as direct object in basic tenses; the other is a bound, suffixed set, used as Intransitive Copy Pronoun, indirect object, and also, in the case of some verbs and tenses, as direct object. The bound set is often the same as or very similar to the possessive pronoun set. On the basis of the pattern of pronoun sets found in the languages most closely related to Hausa (see Kraft 1974, Schuh 1978), one can also reconstruct two object pronoun paradigms for Proto-Hausa:

(18) Free Direct Object Set

$\begin{array}{llll}1 \mathrm{sg} & *_{n i} & 1 \mathrm{pl} & { }^{m u ́} \\ 2 \mathrm{~m} & { }_{k \dot{a}} & 2 \mathrm{pl} & { }^{k} \dot{u} \\ 2 \mathrm{f} & { }_{k i} & & \\ 3 \mathrm{~m} & *_{s i} & 3 \mathrm{pl} & { }^{*} \dot{ } \\ 3 \mathrm{f} & *_{t a} & & \end{array}$

(19) Bound Object Set

$\begin{array}{llll}1 \mathrm{sg} & *-n \dot{o} & 1 \mathrm{pl} & *-m \dot{u} \\ 2 \mathrm{~m} & *-k \grave{o} & 2 \mathrm{pl} & *-k \dot{u} \\ 2 \mathrm{f} & *-k \grave{i} & & \\ 3 \mathrm{~m} & * n i & 3 \mathrm{pl} & *-s \dot{u} \\ 3 \mathrm{f} & *-t o ̀ & & \end{array}$

Reflexes of the entire free set (18) can still be seen, e.g. in the direct abject pronouns of gr. 1 verbs, e.g. yaa kaamia ni 'he caught me', yaa mamia $k a$ 'he caught you', etc. The original bound set (19) is no longer so evident, and synchronically its existence has never been suggested. vertheless, in some respects it is not so different from the direct object plonouns of gr. 2 verbs. For example, as recognized clearly by Pilszczikowa (1969), the object pronouns of gr. 2 verbs must be treated as suffixes, which are more tightly bound to the verb than are the object pronouns 
of gr. 1 verbs. Second, these pronouns are characterized by Lo tone (see sec. 3.2 .2 following). ${ }^{13}$ Note, moreover, that if the bound set (includint the pronoun forms $n \dot{0}, k \dot{\delta}, t \grave{0}$ ) represented the paradigm that gr. 2 verbs used as direct objects, one would have, in some persons at least, the missing conditioning factor for the $i i$ to ee change. I would like to suggest, therefore, that this in fact was the case: the bound pronoun set as reconstructed in (19) originally constituted the direct object paradigm of gr. 2 verbs. The consequences of this assumption in terms of the vowel lowering rule and the -i/-ee alternation can be seen in the following examples:

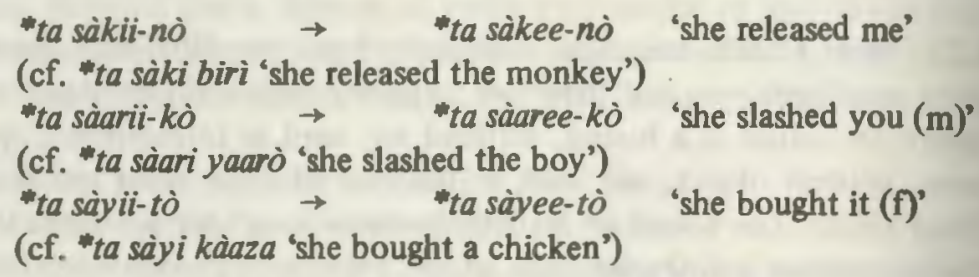

The pronouns not ending in - $o$ would not have conditioned the vowel lower. ing and thus for some period of time there would have been surface variation in the verb forms:

$\begin{array}{ll}\ldots \text {... sàkee-nò } & \text {... sàkiì-mù } \\ \ldots \text { sàkee-kò } & \ldots \text { sàkii-kù } \\ \ldots \text { sàkii-ki } & \\ \ldots \text {... sàkii-ni } & \ldots \text { sàkii-mù } \\ \ldots \text { săkee-tò } & \end{array}$

Subsequently, two things happened: (a) the entire bound pronoun paradigm (except for tone) was replaced by the free object set, as a result of which sàkee-tò, for example, became sàkee-tà; and (b) the verb final-ee was reinterpreted as a pre-pronoun marker and spread to all persons, including those where it was not phonologically conditioned by the form of the pronoun, e.g. "sàkii-mù > sàkee-mù. Exactly how these two factors related to one another sequentially or causally I cannot say; but the result was a completely restructured system in which the evidence for the originally phonological basis of the -ee before pronoun objects, and thus of the $-i$-ee alternation, was completely obliterated.

3.2.2. Generally speaking, direct object pronouns in Hausa are described as having polar tone, i.e. being opposite in tone to the tone of the preceding syllable, e.g. 
(22) grade 1

... dásìa tá 'transplant it' ... sàkée tà 'release it'

... ciràa ká 'raise you' grade 2

... tàmbàyée kà 'ask you'

With gr. 1 verbs of more than 2 syllables, however, the polarity rule fails to apply, e.g.

$$
\begin{aligned}
& \text {... dáakùsáa tả 'blunt it' (not ??daiakùscia tà) } \\
& \text {... tsóoràtća } k a ́ \text { 'frighten you' }
\end{aligned}
$$

A further exception to the tonal polarity rule is provided by gr. 1 verbs in the imperative regardless of the number of syllables, e.g.

$$
\begin{aligned}
& \text { dàsaia tá 'transplant it!' } \\
& \text { tsòoràtóa tá 'frighten her!' }
\end{aligned}
$$

In most accounts of Hausa, these violations of the tonal polarity rule are simply shunted aside. The only serious attempt to account for these anomalous forms is by Leben (1971), who offers an ingenious solution based on the extrinsic ordering of the pronoun polarity rule and another (well-motivated) rule that raises final Lo-Lo sequences to Lo-Hi if the final vowel is long, e.g.

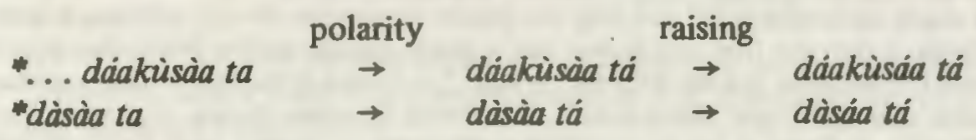

The real explanation for the exceptions to the polarity rule, however, is that there is no polarity! The tones of the pronouns in (23) and (24) are $\mathrm{Hi}$ simply because they are inherently $\mathrm{Hi}$. The difference in tone between the direct object pronouns of $\mathrm{gr} .1$ verbs (always $\mathrm{Hi}$ ) and those of $\mathrm{gr} .2$ verbs (always Lo) ${ }^{14}$ is due, not to synchronic tonal polarity, but to the fact that historically they derive from two different pronoun paradigms, the free set (18) in the first case, the bound set (19) in the other, e.g. ... daisàa tả < daisàa tá vs.... sàkée tà < *àkée- tò.

\section{SUMMARY}

Proto-Hausa can be reconstructed with the following 2-3-5 vowel system: 


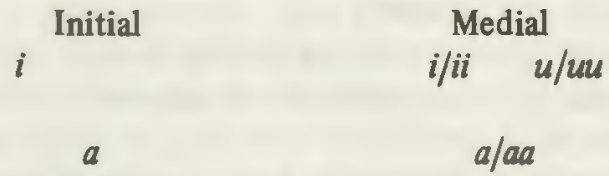

$e_{a}^{\text {Final }} o^{u}$

The major source of the medial $e e$ 's and $o o$ 's that are found in present-day Hausa was a regular sound law lowering long high vowels to mid in the environment of a following mid vowel. This sound law accounts for phonotactic patterns in the nominal system and helps to explain synchronic vowel alternations in the verbal system, namely the ee/oo vs. ii/uu alternation between verbs and "ablauted" verbal nouns, and the $-i$ vs. -ee alterna. tion between the pre-noun and pre-pronoun forms of grade 2 verbs.

\section{NOTES}

1. In many Bole group languages, final $/ \mathrm{a} /$ in monosyllabic verbs is long. This could possibly be a feature going all the way back to Proto-West Chadic. The source for all of the Bole group examples and PB reconstructions cited in this paper is Schuh (1978). 2. In citing examples, real or reconstructed, long vowels are indicated by double vowels, short vowels by a single vowel. Lo tone is indicated by a grave accent (à or àa); Hi tone is usually left unmarked, although where needed it is indicated by an acute accent (á or da). Hypothetical forms are marked by *. Ungrammatical forms are marked by ??.

3. Schuh proposes that the lost article was a previous reference marker *-i. Greenberg does not attempt to reconstruct the article as such, but does assume that it was a single form which did not vary for gender or number. In my opinion, a better hypothesis is that the lost article was not a single vocalic suffix, but rather was a gender/ number sensitive deictic with two forms: * $n$ (plus lengthening of the preceding vowel) with masculine and plural nouns, "-aat with feminine nouns, e.g. mijii "husband" < *mizìin < *mizì + -n; wutaa 'fire' < *wutaat < *wuti + - aat. For a similar process of morphophonological lengthening before the article $-n$ in Bade, see Schuh (1974) 75); for the idea of the feminine - $t$ in Hausa being part of the noun stem, see Skinner (1975).

4. The best example of a direct /i/ vs. / $/ \mathrm{c}$ contrast in a comparable environment is the following pair taken from the Gwandara "dialect" (Matsushita 1972): buci "ashes' vs. bíri monkey", cf. PB "buto and "bido, respectively.

5. This is not to say that PH didn't have palatal consonants - I think that it did but that in most cases, palatal consonants come from a process of palatalization in the environment of a front vowel.

6. Parsons (1970) analyzes Hausa long vowels as sequences of short vowel + semlvowel, i.e. $\mathrm{ii}=\mathrm{iy}, \mathrm{uu}=\mathrm{uw}, \mathrm{aa}=\mathrm{ah}$, and $\mathrm{ee}$ and $\mathrm{oo}=\mathrm{ah}$ with extensive $\mathrm{Y}$ and $\mathrm{W}$ pros ody. While the system might work for ii and uu - and in a few words is historically accurate - there is nothing to recommend it for aa, ee, or oo. From a Chadic perspective, the long vowels are best treated as long vowels. My use of double letter (i.e. a for $\bar{a}$ ) is simply a transcription device. For purposes of this paper, I have ignor ed the diphthongs /ai/ and /au/, even though synchronically 1 consider them as tro diphthongs and not as sequences of vowel + semivowel (Newman 1978).

7. Note that buushiya could not come directly from the phonologically permy sible form "buusi since the feminative of nouns with underlying Hi tone -1 is forme with -aa, not -iyaa. This morphological rule and the vowel lowering rule, taken to gether, explain why feminine nouns ending in -íyáa are not normally proceded b? long high vowel, a phonotactic restriction not previously noted. 
8. The grammatical distinction between the various verbal noun forms in Hausa has never been adequately described. I am indebted to Claude Gouffé (through personal communication) for helping to clarify my ideas on the subject.

9. In CVCV verbs (apart from grade 3 verbs which end in $-a$ ), a semivowel in $\mathrm{C}_{2}$ position is always $/ y /$, not $/ w /$. If the underlying final vowel of the verb were a back, rounded vowel, one would expect the restriction on the occurrence of the semivowels to be the opposite.

10. For an explanation of the Hausa "grade system", see Parsons (1960) and New$\operatorname{man}(1973)$.

11. Leben and Bagari (1975) have presented arguments why synchronically one might want to continue to treat the citation form with final -aa as basic. In any case, this would not affect the historical claim about the basicness of the -i form.

12. The probable explanation for the $-\mathrm{as}$ form is to be found hidden away in a footnote in Lukas (1963:168n), namely that it originally was a verbal noun which came to be used in place of the finite verb when no object was expressed.

13. Perhaps more consistent with the idea that these pronouns are suffixes is Pilszczikowa's (1969) analysis, in which the pronouns have no tone of their own, but rather are assigned tone in accordance with the general tonal pattern of the verb stem. I shall, nevertheless, continue to treat them as inherently Lo in order to contrast them with the inherently Hi free direct object pronouns.

14. In the imperative, the direct object pronoun of a gr. 2 verb is high, e.g. sayde-ta buy it!'. This is because the object suffix has been fused in the verb stem before the assignment of the Lo ... Hi imperative pattern.

\section{REFERENCES}

Abraham, R.C. 1959. The Language of the Hausa People. London: University of London Press.

Grenberg, Joseph H. 1978. How does a language acquire gender markers? In Universals of Human Language Volume 3: Word Structure, ed. J.H. Greenberg, pp. 47-82. Stanford: University Press.

Ningenheben, A. 1927/28. Dic Silbenauslautgesetze des Hausa. Z. f. Eingeborenen Sprachen 18: 272-97.

-1930/31. Ablaut in Afrika. Z. f. Eingeborenen Sprachen 21:81-98.

Kraft, Charles H. 1974. Reconstructions of Chadic pronouns I: Possessive, object, and independent sets - an interim report. In Third Annual Conference on African Lnguistics, ed. E. Voeltz, pp. 69-94. (Indiana University Publications, African Series, 7.) Bloomington.

Leben, W.R. 1971. The morphophonemics of tone in Hausa. In Papers in African Linguistics, ed. C.W. Kim and H. Stahlike, pp. 201-18. Edmonton: Linguistic Research, Inc.

Loben, W.R., and D.M. Bagari. 1975. A note on the base form of the Hausa verb. Stud. Afr. Ling. 6:239-48.

Inkas, J. 1937/38. Der Hamitische Gehalt der Tschadohamitischen Sprachen. Z. $f$. Pureborenen Sprachen 28:286-99.

1963. Der II. Stamm des Verbums in Hausa. Afr. u. Ubersee 47:162-86. Mtwushita, Shuji. 1972. An Outline of Gwandare Phonemics and Gwandara-English Vocobulary. (Study of Languages and Cultures of Asia and Africa, 3). Tokyo.

lietman, Paul. 1973. Grades, vowel-tone classes and extensions in the Hausa verbal grtem. Stud. Afr. Ling. 4:297-346.

1975. Proto-Chadic verb classes. Folia Orientalia (Cracow) 16:65-84.

1976. The origin of Hausa $/ \mathrm{h} /$. In Pupers in African Lingulstics in Honor of 
Wm. E. Welmers, ed. LM. Hyman, L.C. Jacobson, and R.G. Schuh, pp. 165-75. (Studies in African Linguistics, suppl. 6).

—. 1977. Chadic classification and reconstructions. Afroasiatic Ling. 5(1):1-42. 1978. Nasal diphthongs in Hausa. Paper presented at the "Friday Club" of the Department of Linguistics, University of Amsterdam. Unpublished ms. - 1979. Explaining Hausa feminines. Stud. Afr. Ling. 10:197-226.

Parsons, F.W. 1960. The verbal system in Hausa. Afr. U. Übersee 44:1-36. - 1970. Is Hausa really a Chadic language? Some problems of comparative phonology. Afr. Lang. Stud. 11:271-88.

-1975. Hausa and Chadic. In Hamito-Semitica, ed. J. and T. Bynon, pp.421-55. The Hague: Mouton.

- n.d. Alphabetical list of all the common disyllabic nouns in Hausa having distinct plural forms in regular use. Mimeographed.

Pilszczikowa; Nins. 1969. The Changing Form (Grade 2) of the Verb in Haum. Warsaw: Pahstwowe Wydawnictwo Naukowe.

Schuh, Russell G. 1974/75. Nunation and gender in Bade. Afr. u. Übersee 58:106-19. _-.. 1977. West Chadic verb classes. In Papers in Chadic Linguistics, ed. P. Newman and R.M. Newman, pp. 143-66. Leiden: Afrika-Studiecentrum.

- 1978. West Chadic vowel correspondences. Paper presented at the Third International Hamito-Semitic Congress (London). Unpublished ms.

Skinner, Neil. 1975. The Hausa genitive morpheme as an exponent of gender: a query. In Hamito-Semitica, ed. J. and T. Bynon, pp. 389-94. The Hague: Mouton.

Department of African Linguistics University of Leiden 